\title{
Bacterial clay authigenesis: a common biogeochemical process
}

\author{
Kurt O. Konhauser ${ }^{a, *}$, Matilde M. Urrutia ${ }^{b}$

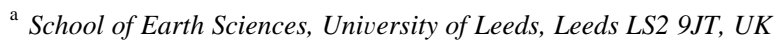 \\ b Department of Biological Sciences, The University of Alabama, Box 870206, Tuscaloosa, AL 35487-0206, USA
}

Received 5 January 1998; accepted 10 November 1998

\begin{abstract}
Transmission electron microscopic (TEM) analyses of freshwater biofilms and bacterial cells, grown in experimental culture, have shown that these microorganisms are commonly associated with fine-grained ( $\mathrm{Fe}, \mathrm{Al}$ )-silicates of variable composition. The inorganic phases develop in a predictable manner, beginning with the adsorption of cationic iron to anionic cellular surfaces, supersaturation of the proximal fluid with $\mathrm{Fe}^{3+}$, nucleation and precipitation of a precursor ferric hydroxide phase on the cell surface, followed by reaction with dissolved silica and aluminum and eventually the growth of an amorphous clay-like phase. Alternatively, colloidal species of ( $\mathrm{Fe}, \mathrm{Al}$ )-silicate composition may react directly with either the anionic cellular polymers or adsorbed iron, depending on their net charge. Over time, these hydrous precursors may dehydrate and convert to more stable crystalline phases. Because microbial biofilms are expansive and highly reactive surfaces at the sediment-water interface, coupled with their ability to bind soluble components and form solid inorganic phases, they should influence the chemical composition of the overlying aqueous microenvironment, and ultimately contribute to the makeup of river bottom sediment. (C) 1999 Elsevier Science B.V. All rights reserved.
\end{abstract}

Keywords: Bacterial; Clay; Authigenesis

\section{Introduction}

The attachment and growth of microorganisms on submerged surfaces are common in flowing rivers (Geesey et al., 1978; Mills and Maubrey, 1981; Ferris et al., 1989). The complex microbial communities that develop on substrata are commonly referred to as biofilms, and consist primarily of a consortia of bacterial microcolonies held firmly together in a highly hydrated polymeric matrix of polysaccharides extruded by the cells (Costerton et al., 1994, 1995). These extracellular materials often

\footnotetext{
* Corresponding author. Tel. +44-113-233-5225; fax: +44113-233-5259; e-mail: k.konhauser@earth.leeds.ac.uk
}

extend several micrometers from the bacterial cell wall (Bayer and Thurrow, 1977), and enable bacteria to adhere to substrata (Little et al., 1997), where, through active growth and cell division, they expand in surface coverage, eventually forming biofilms which cover exposed surfaces (Costerton et al., 1994, 1995). The time required for the formation of a continuous monolayer of cells under laboratory conditions can be as little as 10-30 min (Characklis, 1973), with the accumulation of bacteria on submerged limestone in two Ontario rivers, e.g., numbering in excess of $10^{7} \mathrm{cfu} / \mathrm{cm}^{2}$ in just 21 days (Ferris et al., 1989).

The external polymers surrounding bacterial cells are openly exposed to diffusible components (e.g., 
metal ions) in the bulk aqueous phase (Little et al., 1997). Thus, it is imperative that the bacteria have a mechanism to effectively control the concentration of solutes that may actually reach the cell surface (Lewandowski et al., 1995). This may be accomplished, in part, through interactions with reactive amphoteric groups contained within the constituent polymers of bacterial cell walls and external sheaths and capsules (Beveridge, 1989). These include carboxyl and phosphate groups in the cell wall and outer membrane, as well as carboxyl and hydroxy groups in the surrounding capsules and sheaths (Beveridge and Fyfe, 1985). At the normal growth $\mathrm{pH}$ (between 5 and 8), these polymers are ionised and naturally anionic (Beveridge, 1989), with existing $\mathrm{p} K_{\mathrm{a}}$ models suggesting that deprotonation of carboxyl groups occurs predominantly at $\mathrm{pH}=4.8$ and phosphate groups at $\mathrm{pH}=6.9$ (Fein et al., 1997).

Some wall and capsular polymers react with dissolved ions as if they were an open ion exchange resin (Marquis et al., 1976), whereas others exhibit more selectivity with a greater partitioning ability (Beveridge and Murray, 1976). In this regard, it is not surprising that biofilms, owing to their chemical reactivity and large surface area, are considered ideal scavengers of metal cations (Geesey et al., 1988). Once bound to the bacteria, these cations reduce the activation energy barriers to nucleation by providing sites where surface chemical interactions can take place and more ions can be sorbed from solution (Mann, 1988). If the bacterial cell surface matches well with the nucleating solid, then the interfacial free energy between the two solids will be smaller than the interfacial free energy between the solid and the solution. This will allow nucleation to take place at lower saturations on the cell than in solution (Stumm and Morgan, 1996). In this way, the bacterium functions as a reactive interface, or template, for heterogeneous nucleation (Ferris, 1997; Warren and Ferris, 1998).

At low metal concentrations, surface complexation is the dominant physico-chemical mechanism of metal immobilisation. However, if a sufficient supply of solutes is available (in excess of mineral solubility), then continued adsorption results in surface site saturation, and once critical supersaturation has been reached, critical nuclei become established (Warren and Ferris, 1998). After bacteria initiate biomineralisation, mineral growth (if the ions are the same as those in the surface) or precipitation (if the ions differ in abundance and type from those of the surface) occurs autocatalytically and abiogenically due to the increased surface area generated by the small grains (Banfield and Hamers, 1997). Both mineral growth and surface precipitation favour the initial formation of amorphous solid phases because they have lower interfacial free energies, and hence, a faster nucleation rate than those of more stable, crystalline phases (Steefel and van Cappellen, 1990).

The type of mineralisation that develops in association with bacteria is inevitably dependent upon the available counter-ions, and hence, the chemical composition of the waters in which the microorganisms are growing (Konhauser, 1997, 1998). Transmission electron microscopy (TEM) of thin sections $(<100$ $\mathrm{nm}$ ) of biofilms, coupled with energy dispersive X-ray spectroscopy (EDS) and selected area electron diffraction (SAED), allows the biominerals associated with individual bacteria to be directly observed and characterised. For example, in freshwater environments, electron microscopy has shown that bacterial cells consistently precipitate $(\mathrm{Fe}, \mathrm{Al})$-silicates of variable composition and structure, with sizes generally < $1 \mu \mathrm{m}$ (Ferris et al., 1987; Konhauser et al., 1993, 1994a, 1998; Tazaki, 1997). Indeed, all bacterial populations examined, regardless of physiology, substrate type (i.e., sediment, plants, different rock types), and aqueous composition, consistently formed similar clay-like material. Similarly, in an electron microscopic study of finely laminated phosphate stromatolites of Upper Jurassic age, poorly crystalline smectite grains were observed to be associated with the biogenic deposits (Sánchez-Navas et al., 1998). These natural studies correlate well with experimental work, using the bacterium, Bacillus subtilis, that similarly demonstrates the ability of bacteria to nucleate fine-grained, amorphous to poorly ordered (Fe, Al)-silicates (Urrutia and Beveridge, 1994, 1995).

Considering that bacterial-clay assemblages are widespread in aqueous environments, there must be some common mechanism that leads to the deposition of these inorganic phases. Furthermore, the ubiquity of biofilms growing on submerged substrates, and their inherent chemical reactivity, suggest that these microbial surfaces must influence the 
mobility of dissolved solutes at the sediment-water interface. This paper reviews some of the riverine environments and culture experiments where clay mineralisation has been observed in association with bacteria, and discusses (i) how these clay-like phases likely form; (ii) the possible advantages that bacterial cells may obtain by forming such inorganic precipitates; and (iii) the implications of bacterial clay authigenesis on the aqueous chemistry of the sediment-water interface.

\section{Bacterial clay authigenesis in nature}

Initial field observations supported the concept of bacterial mediation of secondary fine-grained silicate formation. ( $\mathrm{Fe}, \mathrm{Al}$ )-silicates of low crystallinity were sometimes found associated with bacteria in metalcontaminated lake sediments (Ferris et al., 1987), and iron-silicate crystallites were identified on bacteria and their remains in geothermal environments (Ferris et al., 1986; Konhauser and Ferris, 1996). More recently, several TEM studies of biofilms growing on a variety of submerged solid surfaces in the Rio Solimões, Amazonia, Brazil (Konhauser et al., 1993), the Speed River, Ontario, Canada (Konhauser et al., 1994a), the Brahmani River, Orissa, India (Konhauser et al., 1998), and the Azusa-gawa River, Nagano, Japan (Tazaki, 1997), have confirmed that freshwater bacteria and cyanobacteria are commonly mineralised. The range of mineralisation includes the presence of Fe-rich capsules and fine-grained $(<1 \mu \mathrm{m})$ inorganic grains of (Fe, Al)-silicate composition. Several characteristic properties of these inorganic grains suggest an authigenic origin. First, the vast majority of grains are amorphous to poorly ordered structures (i.e., amorphous grains show no electron diffraction patterns, while poorly ordered grains display diffraction rings), with chemical compositions that in general differ from the detrital material carried in suspension. The origin of those grains attached to cells that are crystalline is more difficult to ascertain, since they have a common clay mineralogy (i.e., illite, kaolin) that may be detrital (Konhauser et al., 1998). Second, the grain types on each individual bacterium have similar chemical compositions. For example, on any particular bacterium, all epicellular grains tend to have similar $\mathrm{Fe}, \mathrm{Si}$ and $\mathrm{Al}$ ratios (see below). Yet, the grains between different bacteria, from the same sample, are often quite varied (i.e., cells within micrometers of each other have different compositions). Because detrital materials are sourced from diverse areas, one would expect an overall variability on both individual bacterial cells, and within a population, if all the attached grains were solely derived from suspended detrital material. Thus, the consistency of grain composition on an individual bacterium suggests that the grains formed in situ. Third, most attached grains exhibit a tangential orientation around the bacterial cells. In experimental studies with bacterial cell envelopes and cell wall material, detrital clays showed a preference for edge-on orientation with cellular surfaces (Marshall, 1968, 1969; Walker et al., 1989). Only with the addition of heavy metals, that acted as cation bridges between negatively charged sites on both the cells and clays, was planar surface binding of clays demonstrated (Walker et al., 1989). Fourth, the generally small size of the particles suggests that the grains formed via chemical reaction with the organic ligands; the initial size of the precipitates is possibly governed by the spacing of the Lewis base groups (Ferris, 1989). In contrast, electrostatic interactions between cell surfaces and riverine clay detritus should allow for the attachment of a relatively wide range of grain sizes.

A pattern of mineral precipitation has become apparent, based on the preceding microscopic studies on biofilm biomineralisation. EDS analyses of encapsulated cells show that extracellular surfaces consistently sequester significant amounts of $\mathrm{Fe}$ from solution, with lesser amounts of other cations. For example, Warren and Ferris (1998) have shown experimentally that $B$. licheniformis accumulated iron to the magnitude of millimole per gram range when normalised to cell dry weight. The preferential binding of iron to cell organic material stems from a favourable combination of valence, hydrated radius, hydration energy and electronegativity (Ferris and Beveridge, 1986). Because metal ions can coordinate several suitably placed Lewis base groups (e.g., oxygen atoms) within organic ligands simultaneously, metals such as ferric iron have a considerable competitive advantage over both protons and monovalent alkali metals or divalent alkaline earth metals (Stone, 1997). Ferric iron is similarly advantaged over other 
transition metals, such as $\mathrm{Co}, \mathrm{Ni}, \mathrm{Cu}$ and $\mathrm{Zn}$, when the ligand site involves oxygen donor atoms (Hughes and Poole, 1989), such as those associated with carboxyl and phosphate groups. Another important consideration in favour of dissolved iron species is their greater concentrations in natural waters as compared to other trace metals (Bowen, 1979). It has even been suggested that under circumneutral conditions, any bacterium that produces acidic, extracellular polymers will non-specifically adsorb cationic iron (Ghiorse, 1984). This is due to the point of zero charge (PZC, $\mathrm{pH}$ where the mineral has zero charge) of ferrihydrite being in the range of 5.3-7.5 for natural samples (Schwertmann and Fechter, 1982). This allows reactive organic sites to scavenge ferric iron from the surrounding waters. It should be noted that the PZC of pure ferrihydrite is predicted at 8.8-9.4 (Sverjensky and Sahai, 1996); thus, microorganisms grown in controlled cultures should be more effective accumulators of ferric iron than natural biofilms. A natural corollary to the reactivity of microorganisms for iron is the observation that organic matter commonly adsorbs onto sediment $\mathrm{FeOOH}$ surfaces through ligand exchange with surface $\mathrm{Fe}(\mathrm{OH})_{2}^{+}$and $\mathrm{FeOH}$ groups (Tipping, 1981).

The Fe-rich sites in microbial cell walls and capsules serve as kinetically favourable sites for iron hydroxide growth, and the potential formation of clay-like inorganic phases. It has been shown experimentally that a continuum exists between cationic iron sorption and precipitation reactions at bacterial surfaces; with the three stages of (i) sorption, (ii) surface site saturation and (iii) precipitation all evident in Langmuir-type isotherms relating the solidphase concentration of $\mathrm{Fe}$ (III) to the equilibrium proton and soluble $\mathrm{Fe}$ (III) concentrations (Warren and Ferris, 1998). This relationship is defined by the equation:

$\mathrm{BH}+\mathrm{Fe}_{\mathrm{D}}^{3+}+2 \mathrm{H}_{2} \mathrm{O} \leftrightarrow \mathrm{BFe}(\mathrm{OH})_{2}+3 \mathrm{H}^{+}$,

where $\mathrm{BH}$ represents a bacterial surface site, $\mathrm{BFe}(\mathrm{OH})_{2}$ is bacterially associated solid-phase $\mathrm{Fe}$ and $\mathrm{Fe}_{\mathrm{D}}^{3+}$ is soluble iron. In the transition from sorption to ferric hydroxide precipitation, equilibrium $\left[\mathrm{Fe}_{\mathrm{D}}^{3+}\right] /\left[\mathrm{H}^{+}\right]^{3}$ ratios increased beyond the solubility limits for ferric hydroxide, implying that oversaturation of soluble ferric iron is required to initiate stable critical nuclei that can ultimately sustain crystal growth (Warren and Ferris, 1998).

In natural samples, bacterial cells also show the formation of small ( $\sim 100 \mathrm{~nm}$ in diameter), dense, Fe-rich aggregates on the outer surfaces of capsules (Fig. 1A). These aggregates appear to have formed at a very early stage of mineralisation within metalloaded cells. More commonly, however, the Fe-rich sites on the cell surface serve as precursors to more complex surface precipitates of variable clay composition, morphology and structure. This clayey material presumably uses some fraction of the precursor surface as a template for its own growth, in effect circumventing the need for direct nucleation (Steefel and van Cappellen, 1990). Once it begins to grow, the more stable clay phase increases its own surface area until it can control the composition of the proximal solution. When this happens, the saturation state of the solution moves below the solubility of the precursor, inhibiting further growth, or even dissolving the precursor (Steefel and van Cappellen, 1990). Progressive mineralisation then leads to the partial (Fig. 1B) and complete (Fig. 1C) encrustation of some bacterial cells. Similar biomineralisation is also shown to occur on cyanobacterial cells collected from the same sampling locations (Fig. 1D). In the biofilms from the Brahmani River, e.g., a very high density of clayey materials surround the cells, extending up to $600 \mathrm{~nm}$ from the cell wall (Fig. 2). As discussed above, the authigenic grains from all riverine samples have several characteristic properties. They are generally amorphous to poorly ordered structures with sizes $<1 \mu \mathrm{m}$, although the majority of grains are $<100 \mathrm{~nm}$; they are commonly attached in a tangential orientation around lightly encrusted cells, while those on heavily encrusted cells have a more random orientation; and the grains also have a

Fig. 1. TEMs of encrusted epiphytic bacteria (stained with uranyl acetate and lead citrate) from the Rio Solimões, Brazil. (A) Formation of dense Fe-rich aggregates in capsule (arrow). Scale bar $=360 \mathrm{~nm}$. (B) Partially encrusted cell with amorphous to poorly ordered grains forming within capsule from precursor Fe-rich aggregates. Scale bar $=370 \mathrm{~nm}$. (C) Completely encrusted cell with poorly crystalline to crystalline clayey material. Scale bar $=560 \mathrm{~nm}$. (D) Cyanobacterial cell encrusted in similar clayey material. Scale bar $=610 \mathrm{~nm}$. 

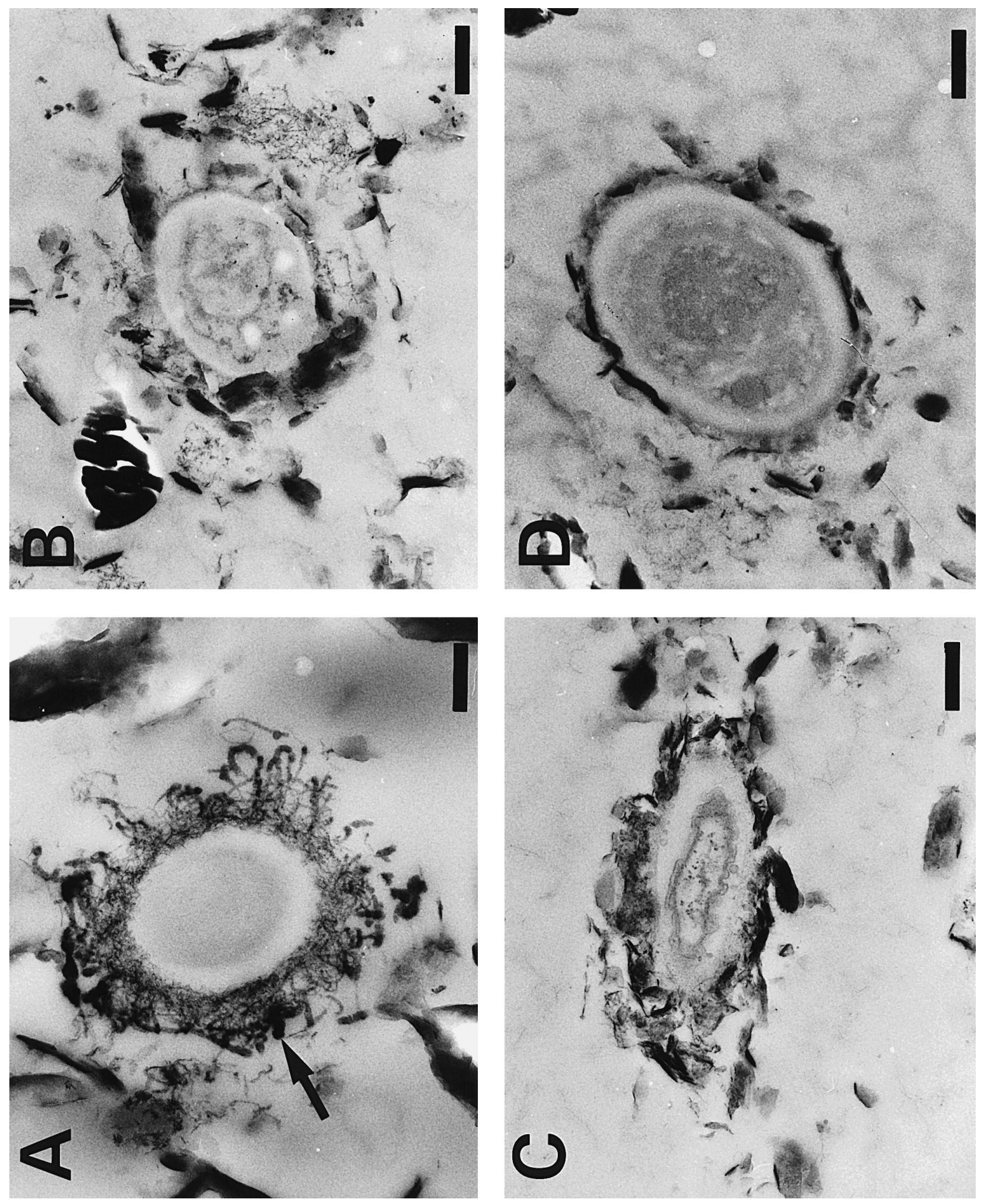


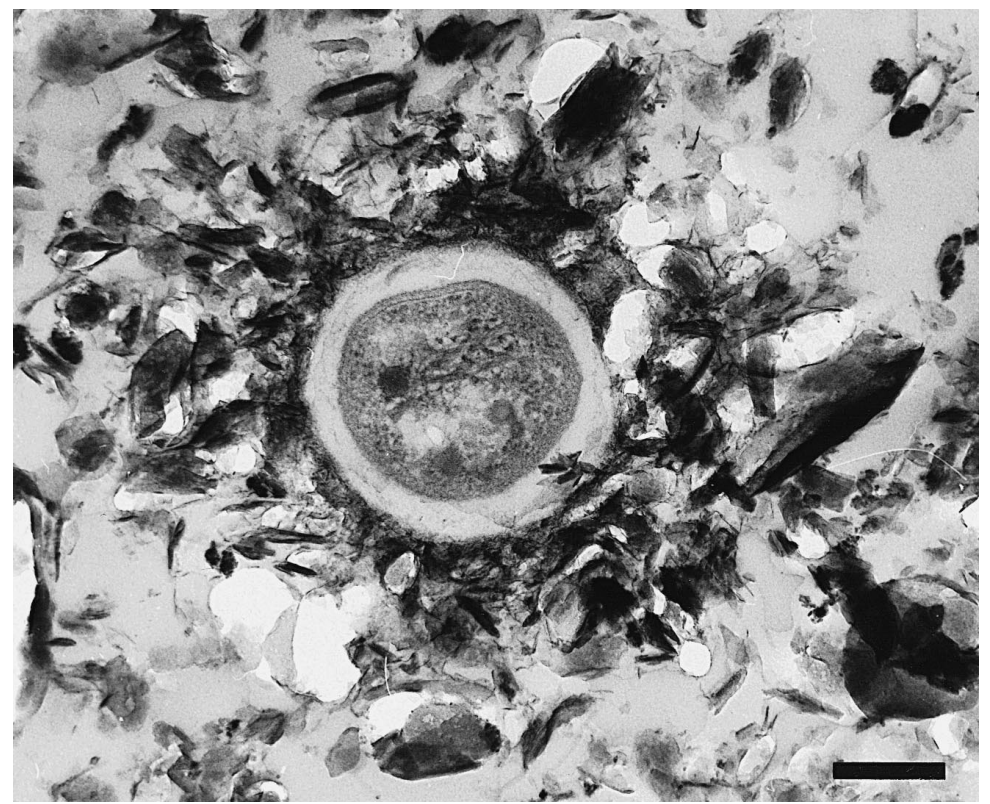

Fig. 2. TEM of a heavily mineralised epilithic bacterial cell, from the Brahmani River, with abundant amorphous and poorly ordered grains on cell wall and within encompassing extracellular polymers. Scale bar $=320 \mathrm{~nm}$.

composition dominated by iron, silicon and aluminum, in varying amounts. With the exception of potassium, no other metals are detected in association with the clay-like phases. A ternary plot of Fe, $\mathrm{Si}$, and $\mathrm{Al}$ (on an atomic percent basis), with the position of various ideal clay minerals labeled (Fig. 3 ), shows that many of the grains are similar to chamosite $\left[(\mathrm{Fe})_{3}\left(\mathrm{Si}_{3} \mathrm{Al}\right) \mathrm{O}_{10}(\mathrm{OH})_{2}\right]$, while other grains have compositions ranging from glauconite $\left[\mathrm{K}\left(\mathrm{Al}_{0.38} \mathrm{Fe}_{1.28} \mathrm{Mg}_{0.34}\right)\left(\mathrm{Si}_{3.7} \mathrm{Al}_{0.3}\right) \mathrm{O}_{10}(\mathrm{OH})_{2}\right]$ to muscovite $\left[(\mathrm{Al})_{2}\left(\mathrm{Si}_{3} \mathrm{Al}\right) \mathrm{O}_{10}(\mathrm{OH})_{2} \cdot \mathrm{K}\right]$ and illite $\left[(\mathrm{Al})_{2}\left(\mathrm{Si}_{4-x} \mathrm{Al}_{x}\right) \mathrm{O}_{10}(\mathrm{OH})_{2} \cdot \mathrm{K}_{x}\right]$, to those approaching the composition of the group of clays, kaolin $\left[\mathrm{Al}_{2} \mathrm{Si}_{2} \mathrm{O}_{5}(\mathrm{OH})_{4}\right]$.

It is likely that the initial $(\mathrm{Fe}, \mathrm{Al})$-silicate phases precipitated directly when dissolved silica and aluminum reacted with cellularly bound iron via hydrogen bonding between the hydroxyl groups in the bound iron with the hydroxyl groups in dissolved silica and aluminum. The iron itself could either be simple hydrated ions that adsorbed to the cellular surface, or they may be solid-phase precipitates, formed from supersaturated proximal fluids. The charge of the iron phase is strongly $\mathrm{pH}$-dependent.
At circumneutral $\mathrm{pH}$, therefore, negatively charged counter-ions accumulate near the solution-adsorbed iron/solid interface to neutralise the net positive charge of iron. This arrangement of ions forms an electric double layer, with iron attaching to the bacterial surface as an inner sphere complex, while dissolved silica and aluminum attach as more diffuse outer layers (Stumm and Morgan, 1996). This mechanism of binding $\mathrm{Fe}$ to the bacterial cell wall and subsequent reaction with $\mathrm{Si}$ and $\mathrm{Al}$ from solution were also shown in experimental systems, which are subsequently discussed in this review. Alternatively, colloidal species of (Fe, Al)-silicate composition, that either form initially in the water column or are products of weathering and soil formation, may react directly with the cellular polymers and/or adsorbed metal ions (Ferris et al., 1987). It follows that anything which will neutralise or diminish the charge of the colloids (e.g., bacterial surface if colloids are positively charged or adsorbed iron if the colloids are negatively charged) will cause the particles to flocculate out of solution (Stumm and Morgan, 1996). If the microbial mats are subject to sufficiently concentrated solutions, then the cells can become com- 


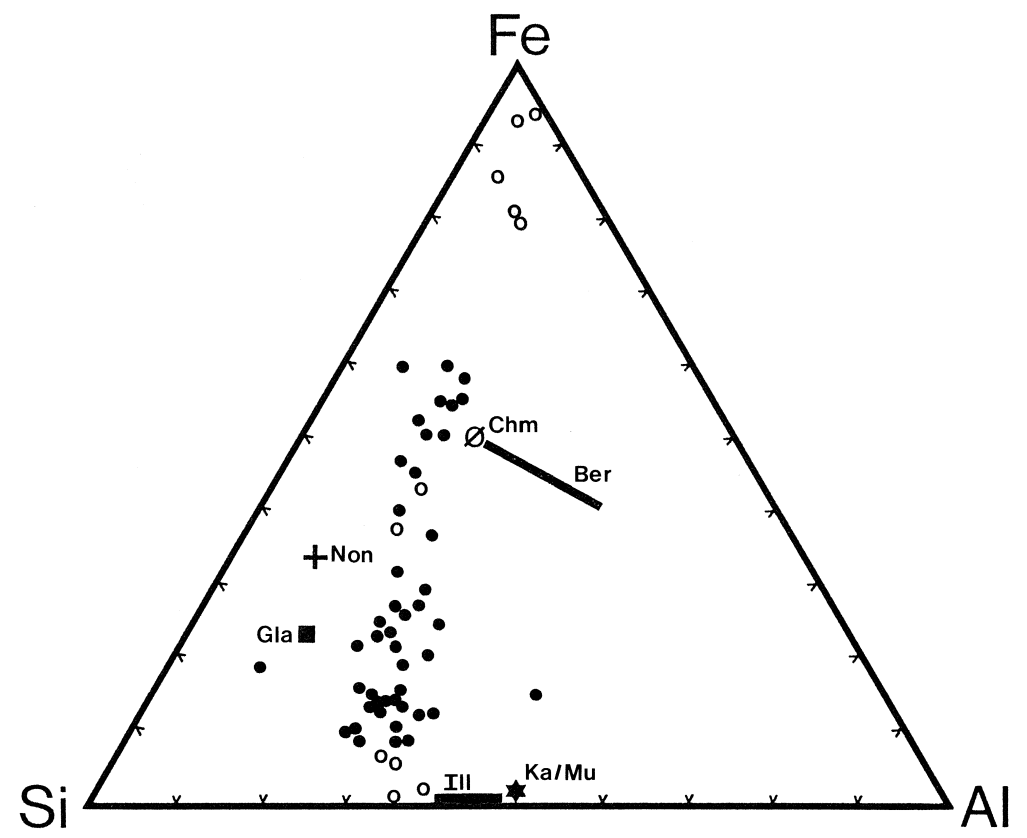

Fig. 3. Distribution of $\mathrm{Fe}, \mathrm{Al}$ and $\mathrm{Si}$ (on an atomic percent basis) in all grains analysed (60 in total) from six epilithic bacterial cells collected from the Brahmani River. Amorphous to poorly ordered grains (closed circle) and crystalline grains (open circle) are compared with several ideal clay minerals, including chamosite ( $\mathrm{Chm}$ - slashed circle), berthierine (Ber - thin, long rectangle to represent variable compositions), kaolin and muscovite ( $\mathrm{Ka} / \mathrm{Mu}$ — closed star), nontronite (Non — cross), illite (Ill — thick, long rectangle) and glauconite (Gla - closed square). One quartz grain ( $\mathrm{Si}$ apex), one gibbsite grain ( $\mathrm{Al}$ apex), one kaolin grain and three illite grains are not shown due to large size of symbols. Modified from Konhauser et al. (1998).

pletely encrusted in clay-like material as abiological surface reactions accelerate the rate of mineral precipitation (Ghiorse, 1984). In solute-deficient rivers, such as the Rio Negro, Brazil (Konhauser et al., 1994b), bacteria show a conspicuous absence of mineralisation (Konhauser et al., 1993). This suggests that the bacteria are only able to bind enough metals to fulfill physiological requirements, not the relatively large quantity of metals necessary to form authigenic biominerals.

Continued aggregation of these hydrous precursors eventually results in the formation of amorphous to poorly ordered inorganic phases, with a chemical composition similar to chamosite (or berthierine). Over time, these hydrous compounds dehydrate, with some phases converting to more stable crystalline forms. Ferris et al. (1987) found that an increasing incorporation of $\mathrm{Fe}$ (in a metal-contaminated lake sediment) accompanied the conversion of the poorly ordered $(\mathrm{Fe}, \mathrm{Al})$-silicates into a crystalline form of chamosite. In the biofilms from the Rio Solimões, the Speed River and the Brahmani River, the hydrous precursor phases appeared especially reactive to silicic acid $\mathrm{Si}(\mathrm{OH})_{4}$ and dissolved potassium. Continued adsorption of these dissolved ions, and denaturing through hydrogen bonding of the hydroxyl groups in the bound cations with the hydroxyl groups in the silica, seem to have accompanied the solid-state transformation from the amorphous and poorly ordered chamosite-like phases to more crystalline phases. A similar growth pattern, involving decomposition and crystallisation, is observed in the glauconitisation of precursor layered, clay-like phases (Amouric and Parron, 1985), while Sánchez-Navas et al. (1998) have suggested that the authigenic smectites, associated with phosphatic stromatolites, were derived from the crystallisation of an amorphous $\mathrm{Fe}-\mathrm{Si}-\mathrm{Al}$ precursor. A ternary plot of $\mathrm{K}, \mathrm{Si}$ and $\mathrm{Al}$ (on an atomic percent basis) from samples collected in the Brahmani River, with glauconite, 
muscovite, illite and kaolin labeled (Fig. 4), clarifies that all of the amorphous grains cluster around illite. This indicates that as the amorphous grains become more siliceous (and relatively less ferruginous), their composition becomes more similar to illite (Konhauser et al., 1998).

The preferential accumulation of silica during the final stages of mineralisation may either reflect the higher concentration of dissolved silica to dissolved iron in most major rivers (world river average for dissolved silica $=14 \mathrm{ppm}$ and world river average for dissolved iron $=0.5 \mathrm{ppm}$; Bowen, 1979) or the different behaviour of these two elements in the aqueous system. On one hand, dissolved iron readily adsorbs to anionically charged organic material (Beck et al., 1974), including microorganisms. On the other hand, dissolved silica (in the form of silicic acid) has a large negative surface charge (Parks, 1965) which renders silica highly reactive to metal hydroxides (Williams and Crerar, 1985), such as those bound to cells. Similar sorption reactions between dissolved silica and metal hydroxides in sediment typically control silica concentrations in rivers (Edwards and Liss, 1973). Under appropriate conditions, where metal hydroxide sites are available, clay authigenesis may preferentially reduce dissolved silica to levels below quartz saturation (Drever, 1982). At highly acidic $\mathrm{pH}$, however, like those sometimes found in acidic mine tailings $(\mathrm{pH} \sim 2.3$ ), acidophilic bacteria such as Thiobacillus sp. were found to be surrounded by fine-grained silica (Fortin and Beveridge, 1997). This process may be significant in sulphide depleted tailings where the formation of Fe-oxides is negligible.

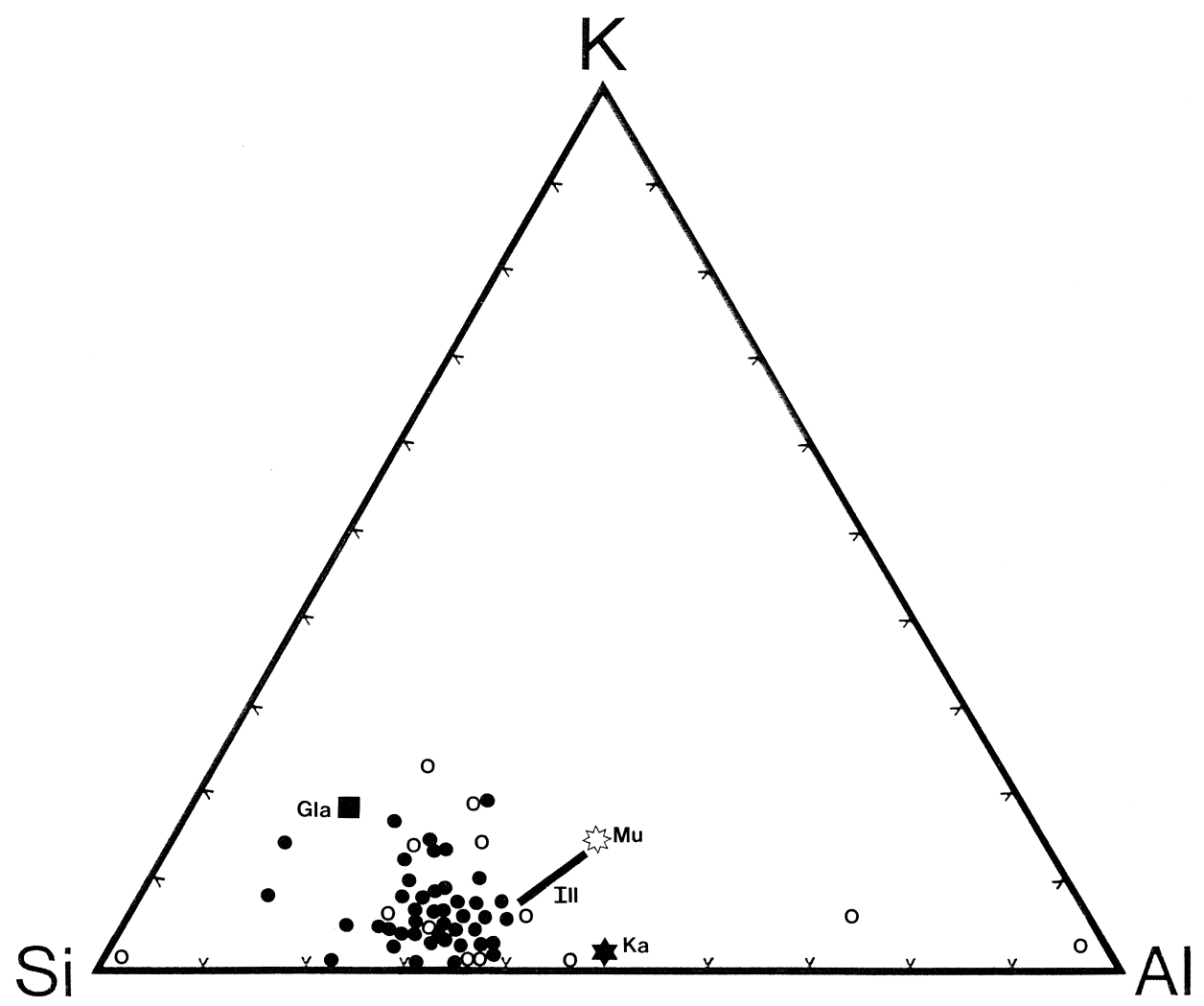

Fig. 4. Distribution of K, Al and Si (on an atomic percent basis) similar to Fig. 3. Several ideal clay minerals, including, kaolin (Ka closed star), muscovite ( $\mathrm{Mu}$ - open star), illite (Ill — long rectangle) and glauconite (Gla — closed square) are labelled. One muscovite grain and one kaolin grain are not shown. Modified from Konhauser et al. (1998). 


\section{Experimental clay formation}

The study of fine-grained silicate mineral nucleation and formation by bacterial surfaces was undertaken in laboratory simulations which mimicked environmental conditions (Urrutia and Beveridge, 1994, 1995). In all these studies, the Gram-positive bacterium $B$. subtilis was chosen because it is an ubiquitous and common soil organism, whose wall chemistry is well-defined (Beveridge and Murray, 1980; Doyle et al., 1980), and whose metal-binding capacity extends to many different metals (Beveridge and Murray, 1976, 1980; Marquis et al., 1976; Mullen et al., 1989). For comparison and as controls, inorganic (abiotic) processes were also studied under the same conditions.

Solutions of metasilicate $\left(\mathrm{SiO}_{3}^{2-}\right), \mathrm{Al}$ and $\mathrm{Fe}$, at concentrations simulating average soil solutions, were first used and then compared to bacterial suspensions with equal chemical composition (Urrutia and Beveridge, 1994). The major differences between abiotic vs. bacterial precipitates are their size and composition. Bacterial crystallites are smaller and contain proportionally less $\mathrm{Si}$; they are chemically more heterogeneous than their abiotic counterparts; and they contain $\mathrm{K}$ and $\mathrm{P}$, presumably of cellular origin since they were not part of the original reaction mixtures. The bacterial precipitates are also less crystalline (as determined by SAED) than the inorganic crystallites. Pure silica $\left(\mathrm{SiO}_{2}\right)$ appears only occasionally in the samples. Interestingly, all these characteristics are also features of the silicate crystallites found in natural riverine environments discussed above (Konhauser et al., 1993, 1994a, 1998).

Silicate anion binding to the bacterial surfaces is enhanced when the bacterial cell walls are preloaded with $\mathrm{Fe}(\mathrm{III})$, particularly at slightly alkaline $\mathrm{pH}$ (8.0) (Fig. 5). Greater binding of Si to the B. subtilis wall occurs if it is added in combination with a variety of heavy metals, compared to conditions when only $\mathrm{Fe}$ and $\mathrm{Al}$ are provided (Table 1). These observations suggest that heavy metal cations participate in sili-

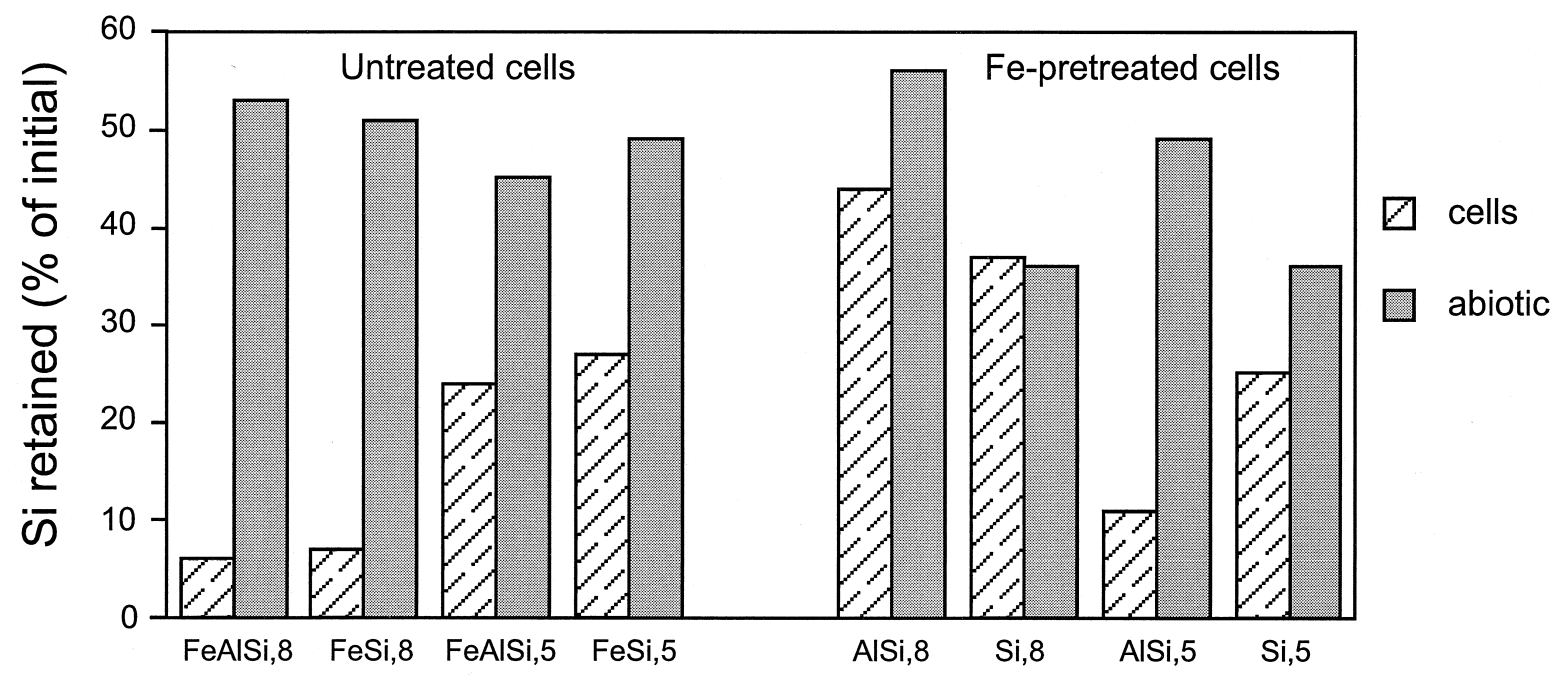

\section{Solution composition}

Fig. 5. Silicon retained (expressed as percentage of the total amount of Si added) after 24 weeks in experimental systems with Fe, Al and $\mathrm{Si}$ as components in several combinations. These are represented by the nomenclature on the $X$-axis, in which the numbers correspond to the respective initial $\mathrm{pH}$ of the mixtures. The legend reflects values obtained in the presence (cells) or in absence (abiotic) of bacteria ( $B$. subtilis). In the tests with untreated cells (left), Fe was provided in soluble form to both bacterial and abiotic control systems. In the samples with Fe-pretreated cells (right), only Fe bound to the cell surfaces was present in biotic systems, no Fe was present in abiotic controls. Reprinted from Urrutia and Beveridge (1994) with the kind permission of the publisher, Elsevier, the Netherlands. 
Table 1

Si immobilised (as percentage of the amount added) in experimental bacterial and abiotic systems under several solution compositions

In the soluble $\mathrm{Fe}$ systems (FeAlSi and $\mathrm{FeSi}$ ), soluble $\mathrm{Fe}$ was provided in the reaction mixture to both bacterial and abiotic samples. In the bacterial Fe systems (AlSi and $\mathrm{Si}$ ), Fe was bound to the cell surfaces previous to mixing with the soluble components; therefore, $\mathrm{Fe}$ was not present in the corresponding abiotic controls. In all four cases, ranges represent data from experiments with initial $\mathrm{pH}$ of 5 and 8 . Silicon and metal experiments $(\mathrm{Si}+$ metals) included $\mathrm{Al}, \mathrm{Cd}, \mathrm{Cr}, \mathrm{Cu}, \mathrm{Fe}, \mathrm{Ni}, \mathrm{Pb}$ and $\mathrm{Zn}$ at an initial $\mathrm{pH}$ of 4.5. Compiled from data presented in (Urrutia and Beveridge, 1994) with the permission of the publisher, Elsevier, the Netherlands.

\begin{tabular}{lcc}
\hline System & Bacteria & Abiotic \\
\hline Soluble Fe systems & & \\
FeAlSi & $6-24$ & $45-53$ \\
FeSi & $7-27$ & $49-51$ \\
Bacterial Fe systems & & \\
AlSi & $11-44$ & $49-56$ \\
$\mathrm{Si}$ & $25-37$ & $28-36$ \\
$\mathrm{Si}+$ metals & $32-40$ & $24-28$ \\
\hline
\end{tabular}

cate binding to bacterial wall surfaces through the formation of ternary complexes (e.g., wall-metalsilicate). In other words, there is a cationic bridging mechanism for silicate binding to the $B$. subtilis walls (Urrutia and Beveridge, 1993). Because the $B$. subtilis surface is predominantly electronegative (due to abundant carboxyl groups), silicate anions can only be electrostatically bound to the limited number of organo-amine groups also present within the wall (Beveridge, 1986). Experiments with B. subtilis cells, whose walls had been chemically modified to become electropositive (Urrutia and Beveridge, 1993), indicate that silicate binding to the bacterial wall can be described as an outer sphere complex formation, involving primarily electrostatic interactions between the silicate anions and positive charges in the wall. These positive charges may be either native organoamine groups or metals bound to the carboxyl or phosphate groups within the wall (Urrutia and Beveridge, 1993). Growth of the precipitates continues after the initial silicate binding, until complex silicate structures are formed. Observations from natural environments directly correspond to these experiments: Fe-rich aggregates form first (Fig. 1A), followed by encrustation in silicate-mineral phases of different composition and crystallinity (Fig. 1B-D). In some cases, the experimental bacterial precipitates correspond to kaolin, while other precipitates are similar to complex 2:1 phyllosilicates (Urrutia and Beveridge, 1994).

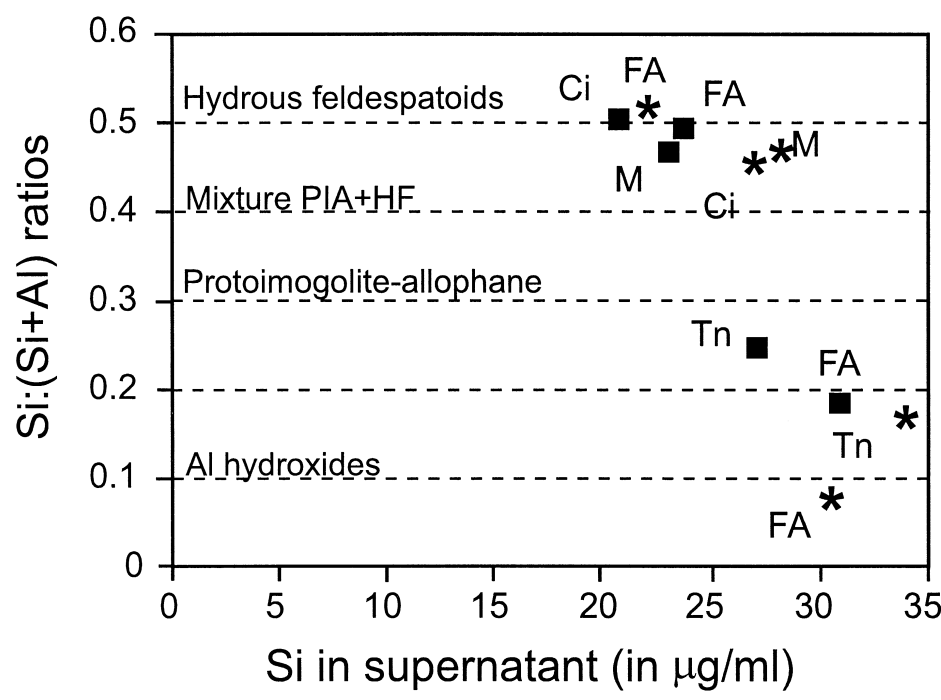

- Bacterial precipitates

* Abiotic precipitates

Fig. 6. Molar $\mathrm{Si} /(\mathrm{Si}+\mathrm{Al})$ ratios in bacterial (B. subtilis) and abiotic precipitates in experimental systems, with $\mathrm{Si}$ in presence of metals (Al, Cd and $\mathrm{Zn})(\mathrm{M})$, metals and citric acid (Ci), metals and tannic acid (Tn) and metals and fulvic acids (FA) at 7 weeks. These values are related to the classification of short-range order aluminosilicates established by Farmer et al. (1991). PIA is protoimogolite-allophane; HF is hydrous feldespatoids. Reprinted from Urrutia and Beveridge (1995) with the kind permission of the publisher, Elsevier, the Netherlands. 
In all cases, bacterially induced neoformed minerals possess low crystallinity. In soils, the best known silicates of low crystallinity are the aluminosilicates, allophane and imogolite. Allophane is defined as a non-crystalline hydrous aluminosilicate of variable morphology (Farmer et al., 1991), and as a group of clay-sized minerals with short-range order that contain silica, alumina and water in chemical combination (Parfitt, 1990). Imogolite is a hydrous aluminosilicate with paracrystalline cylindrical structure (Cradwick et al., 1972) that consists of a tube unit with inner and outer diameters of 1 and $2 \mathrm{~nm}$, respectively (Wada, 1989). Organic acids and ionic factors such as electrolytes inhibit the formation of these minerals in soils (Inoue and Huang, 1985, 1986). As bacterial surfaces can both influence the composition and increase the rate of formation of silicate crystallites (as shown above), the possibility was explored that nucleation of short-range ordered aluminosilicates would proceed in the presence of organic ligands, if bacterial surfaces (i.e., B. subtilis) were available to enhance the binding of the inorganic ions (Urrutia and Beveridge, 1995). The results provided evidence of the ability of bacterial surfaces to participate in the formation of poorly ordered aluminosilicates in the presence of metallic cations and inhibitory substances such as high and low molecular weight organic acids. Typically, the solution $\mathrm{pH}$ of the samples containing bacteria increased to near neutrality; the newly developed inorganic phases contained a greater proportion of silicate than those from the abiotic solutions (Fig. 6), and the remaining solution had greatly reduced levels of soluble metals. These results suggest that mineral neoformation in soils may have an important biotic contribution, which would depend on both the type and quantity of biomass available to interact with soluble organic and inorganic species in the soil solution. We believe that these conclusions can similarly be extended to the fluids above the sedimentwater interface and sediment pore-waters.

\section{Discussion}

The ubiquity of (Fe, Al)-silicate precipitation on freshwater bacterial cell surfaces implies that bacteria facilitate this form of biomineralisation with rela- tive ease, apparently in preference to other minerals that might be supersaturated in the aqueous environment. Perhaps, the fact that most rivers and lakes typically contain high concentrations of iron, relative to other transition metals, and that the bound iron ideally serves as a nucleation site and/or precursor iron hydroxide phase for further reaction with dissolved silica and aluminum, is all that is required for the formation of authigenic clays. Interestingly, however, most world rivers are dominated by dissolved calcium (Berner and Berner, 1996). For example, calcium is the most abundant cation in the Rio Solimões, the Azusa-Gawa River, the Speed River and the Brahmani River; the latter two rivers having an aqueous chemistry which, based on elevated bicarbonate and calcium concentrations, as well as a $\mathrm{pH} \sim 8$ (unpublished data for Speed River; Konhauser et al., 1997), appear to be supersaturated with respect to calcium carbonate. Yet, calcium carbonate precipitation is not observed on bacterial cell surfaces, even though some bacteria (e.g., Synechoccus sp.) can induce calcification in alkaline environments due to a photosynthetic alkalinisation process (Thompson and Ferris, 1990). Presumably, the presence of dissolved iron outcompetes calcium for reactive cellular sites, thereby precluding calcium carbonate precipitation on bacterial cells. This does not imply that calcium carbonate is not precipitating elsewhere in the bulk system, only that it was not evident in association with bacterial cell surfaces. Calcium carbonate is, however, found to form on bacterial cell surfaces today in freshwater, alkaline lakes (Thompson and Ferris, 1990; Thompson et al., 1997) and marine atolls (Défarge et al., 1994), environments depleted in dissolved iron.

It has been established that bacteria have the ability to partially control their surface charge (Doyle, 1989). During metabolism, a membrane-induced proton motive force continuously pumps protons into the wall fabric that effectively compete with metal ions for anionic wall sites (Urrutia et al., 1992). Subsequently, living bacteria may be able to reduce authigenic mineral formation and detrital mineral adhesion on their cellular surfaces, unless environmental conditions exceed their capacity to compensate. In most aqueous environments with low dissolved solutes, this condition should not arise. Therefore, the presence of epicellular minerals on 
bacteria suggests that: (i) the cells had lysed prior to mineralisation; or (ii) that the mineralised matrix is advantageous to the microorganism. Unfortunately, the collection of natural biofilm samples, and their immediate fixation in gluteraldehyde, precludes further study on cell growth. Experimental studies, however, can be designed such that cell viability can be determined. For example, it has been shown that cells of B. subtilis did mineralise during growth in Tryptic-Soy broth agar plates to which $0.1 \%$ Nasilicate had been added; small-sized aggregates started to appear after 14 days of growth, and became very numerous around the cell surface by 20 days of growth. EDS analysis showed aggregate compositions that predominantly corresponded to Ca-silicates (Urrutia, unpublished data). Thus, these observations imply that the precipitates were not detrimental for cell growth, at least in the initial stages of mineralisation. Laboratory studies with Thiobacillus sp. at $\mathrm{pH}=2.3$ also showed no difference in Si retention between viable and dead cells (Fortin and Beveridge, 1997). In this 14-day study, no limitations on cell growth (estimated as cell numbers), due to the presence of $\mathrm{Si}$ in the growth medium, were observed.

Although the nucleation and growth of silicate phases on bacterial surfaces may simply be a fortuitous process, the result of physico-chemical properties of their surfaces with no advantages to the bacterial cells themselves, several lines of evidence suggest that a clay matrix may actually modify the microenvironment around the cells to their advantage (Marshall, 1969; Stotzky, 1985; England et al., 1993). First, clays provide a good source of exchangeable inorganic nutrients readily available to microbes (Stotzky and Rem, 1966; Tazaki et al., 1994). Second, clays such as montmorillonite stimulate the respiration of bacteria by maintaining the $\mathrm{pH}$ of the environment at a level suitable for growth (Stotzky and Rem, 1966). Third, the formation of an external mineralised matrix may protect the living cells from the detrimental effects of toxin-producing microorganisms (Habte and Barrion, 1984) and predation by grazing protozoans (Heynen et al., 1988, Heijnen et al., 1991, 1992; Heijnen and van Veen, 1991).

The chemical composition of waters at the sediment-water interface is influenced by: (i) sedimentation and entrainment of metal-rich particulate material; (ii) metal adsorption onto clays, metal oxides-hydroxides or organic material in the bottom sediment; and (iii) precipitation of metal compounds or coprecipitation of metals by hydrous $\mathrm{Fe}$ and $\mathrm{Mn}$ oxides, carbonates and phosphates (Förstner, 1982; Hart, 1982). The role of microorganisms, in particular biofilms, however, seldom has been considered as an important influencing factor. The thickness of a biofilm may be only a few millimeters at most, yet when one takes into consideration the large surface area of a river bed that is colonised by biofilms, the volume of water that falls directly under microbial contact is substantial. Epilithic microbial biofilms are also highly reactive surfaces, capable of accumulating soluble components from the overlying aqueous microenvironment. In this regard, biofilms dominate the reactivity of the sediment-water interface, and through the adsorption of dissolved constituents, exert an influence on the transfer of dissolved ions from the hydrosphere to the bottom sediment. The bound metals may then become immobilised as stable mineral phases that collect as sediment on the river bed, sections of the metal-laden biofilms may be sloughed off by high flows and transported downstream to be deposited in a receiving lake or reservoir, or the metals may be recycled back into the overlying water column after microbial organic matter mineralisation (Hart, 1982; Beveridge et al., 1983; van Cappellen and Gaillard, 1996). At present, we have not attempted to quantify these processes to determine the net bioaccumulation of metals in the bottom sediment, or for that matter, the actual levels of biogenically formed amorphous clay (e.g., chamosite/berthierine-like phases). Ascertaining their amounts is fraught with difficulty. For example, in studies by Martinelli et al. (1993) and Konhauser et al. (1994b), the dominant ferruginous clays in the Rio Solimões bottom sediments (i.e., those crystalline phases that are detectable by X-ray diffraction) are smectite and illite. Yet, TEM analyses of the same sediments distinctly show bacterial cells completely encrusted in amorphous phases of chamositic composition. Clearly, a fraction of sediment is simply not characterisable with standard $\mathrm{X}$-ray techniques, and thus, current analyses may be somewhat unrepresentative.

Irrespective of above, one clear conclusion can be drawn from this review: that microbial biofilms 
should be viewed as important agents in controlling the aqueous chemistry of the sediment-water interface through the processes of metal deposition and low-temperature silicate mineral formation. The inevitable consequences of bacterial biomineralisation at the sediment-water interface also have important implications for the early diagenetic redox chemistry of iron. In freshwater sediments, amorphous iron hydroxides are considered the most important source of $\mathrm{Fe}$ (III) for $\mathrm{Fe}(\mathrm{III})$-reducing bacteria, with the rate of $\mathrm{Fe}(\mathrm{III})$ reduction declining rapidly at depth as the poorly crystalline $\mathrm{Fe}(\mathrm{III})$ hydroxides become depleted (Lovley and Phillips, 1987); other iron minerals are reduced at much slower rates (Lovley and Phillips, 1986; Roden and Zachara, 1996). To date, the only clear examples of Fe(III)-reduction in clay minerals consist of recent findings by Gates et al. (1993) and Kostka et al. (1996) who have shown that $\mathrm{Fe}^{3+}$ in smectites could be reduced by cultures of iron-reducing bacteria. Notwithstanding, the complete encrustation of bacterial cells by iron and silica phases may present most iron reducers with an inefficient energy source, greatly enhancing the mineral's preservation potential, and in effect, partially controlling the diagenetic pathway of iron in sediments.

\section{Acknowledgements}

We would like to thank Quentin Fisher, Grant Ferris and two anonymous reviewers for their critical reviews.

\section{References}

Amouric, M., Parron, C., 1985. Structure and growth mechanism of glauconite as seen by high-resolution transmission electron microscopy. Clays Clay Miner. 33, 473-482.

Banfield, J.F., Hamers, R.J., 1997. Processes at mineral and surfaces with relevance to microorganisms and prebiotic synthesis. In: Banfield, J.F., Nealson, K.H. (Eds.), Geomicrobiology: Interactions Between Microbes and Minerals. Min. Soc. Am., Vol. 35, Washington, DC, pp. 81-122.

Bayer, M.E., Thurrow, H., 1977. Polysaccharide capsule of Escherichia coli. Microscope study of its size, structure, and sites of synthesis. J. Bacteriol. 130, 991-996.

Beck, K.C., Reuter, J.H., Perdue, E.M., 1974. Organic and inorganic geochemistry of some coastal plain rivers of the south- eastern United States. Geochim. Cosmochim. Acta 38, 341364.

Berner, E.K., Berner, R.A., 1996. Global Environment. PrenticeHall, Upper Saddle River, NJ, 376 pp.

Beveridge, T.J., 1986. The immobilization of soluble metals by bacterial walls. Biotechnol. Bioeng. Symp. 16, 127-139.

Beveridge, T.J., 1989. The structure of bacteria. In: Poindexter, J.S., Leadbetter, E.R. (Eds.), Bacteria in Nature. Plenum, New York, pp. 1-65.

Beveridge, T.J., Fyfe, W.S., 1985. Metal fixation by bacterial cell walls. Can. J. Earth Sci. 22, 1893-1898.

Beveridge, T.J., Murray, R.G.E., 1976. Uptake and retention of metals by cell walls of Bacillus subtilis. J. Bacteriol. 127, 1502-1518.

Beveridge, T.J., Murray, R.G.E., 1980. Sites of metal deposition in the cell wall of Bacillus subtilis. J. Bacteriol. 141, 876-887.

Beveridge, T.J., Meloche, J.D., Fyfe, W.S., Murray, R.G.E., 1983. Diagenesis of metals chemically complexed to bacteria: laboratory formation of metal phosphates, sulfides, and organic condensates in artificial sediments. Appl. Environ. Microbiol. 45, 1094-1108.

Bowen, H.J.M., 1979. Environmental Chemistry of the Elements. Academic Press, London, 333 pp.

Characklis, W.G., 1973. Attached microbial growths: 1. Attachment and growth. Water Res. 7, 1113-1127.

Costerton, J.W., Lewandowski, Z., DeBeer, D., Caldwell, D., Korber, D., James, G., 1994. Biofilms, the customized microniche. J. Bacteriol. 176, 2137-2142.

Costerton, J.W., Lewandowski, Z., Caldwell, D.E., Korber, D.R., Lappin-Scott, H.M., 1995. Microbial biofilms. Annu. Rev. Microbiol. 49, 711-745.

Cradwick, P.D.G., Farmer, V.C., Russell, J.D., Masson, C.R., Wada, K., Yoshinaga, N., 1972. Imogolite, a hydrated aluminum silicate of tubular structure. Nature 240, 187-189.

Défarge, C., Trichet, J., Couté, A., 1994. On the appearance of cyanobacterial calcification in modern stromatolites. Sediment. Geol. 94, 11-19.

Doyle, R.J., 1989. How cell walls of Gram-positive bacteria interact with metal ions. In: Beveridge, T.J., Doyle, R.J. (Eds.), Metal Ions and Bacteria. Wiley, New York, pp. 275293.

Doyle, R.J., Matthews, T.H., Streips, U.N., 1980. Chemical basis for selectivity of metal ions by the Bacillus subtilis cell wall. J. Bacteriol. 143, 471-480.

Drever, J.I., 1982. The Geochemistry of Natural Waters. Prentice-Hall, Englewood Cliffs, NJ, 388 pp.

Edwards, A.M.C., Liss, P.S., 1973. Evidence for buffering of dissolved silicon in freshwaters. Nature 243, 341-342.

England, L.S., Lee, H., Trevors, J.T., 1993. Bacterial survival in soil: effect of clays and protozoa. Soil Biol. Biochem. 25, 525-531.

Farmer, V.C., McHardy, W.J., Palmieri, F., Violante, A., Violante, P., 1991. Synthetic allophanes formed in calcareous environments: nature, conditions of formation and transformations. Soil Sci. Soc. Am. J. 55, 1162-1166.

Fein, J.B., Daughney, C.J., Yee, N., Davis, T.A., 1997. A chemical equilibrium model for metal adsorption onto bacterial surfaces. Geochim. Cosmochim. Acta 61, 3319-3328. 
Ferris, F.G., 1989. Metallic ion interactions with the outer membrane of Gram-negative bacteria. In: Beveridge, T.J., Doyle, R.J. (Eds.), Metal Ions and Bacteria. Wiley, New York, pp. 295-323.

Ferris, F.G., 1997. Formation of authigenic minerals by bacteria. In: McIntosh, J.M., Groat, L.A. (Eds.), Biological-Mineralogical Interactions. Min. Assoc. Can. Short Course Series, Vol. 25, Ottawa, pp. 187-208.

Ferris, F.G., Beveridge, T.J., 1986. Physiochemical roles of soluble metal cations in the outer membrane of Escherichia coli K-12. Can. J. Microbiol. 32, 594-601.

Ferris, F.G., Beveridge, T.J., Fyfe, W.S., 1986. Iron-silica crystallite nucleation by bacteria in a geothermal sediment. Nature 320, 609-611.

Ferris, F.G., Fyfe, W.S., Beveridge, T.J., 1987. Bacteria as nucleation sites for authigenic minerals in a metal-contaminated lake sediment. Chem. Geol. 63, 225-232.

Ferris, F.G., Fyfe, W.S., Witten, T., Schultze, S., Beveridge, T.J., 1989. Effect of mineral substrate hardness on the population density of epilithic microorganisms in two Ontario rivers. Can. J. Microbiol. 35, 744-747.

Förstner, U., 1982. Accumulative phases for heavy metals in limnic sediments. Hydrobiologia 91, 269-284.

Fortin, D., Beveridge, T.J., 1997. Role of the bacterium, Thiobacillus, in the formation of silicates in acidic mine tailings. Chem. Geol. 141, 235-250.

Gates, W.P., Wilkinson, H.T., Stucki, J.W., 1993. Swelling properties of microbially reduced ferruginous smectite. Clays Clay Miner. 41, 360-364.

Geesey, G.G., Mutch, R., Costerton, J.W., Green, R.B., 1978. Sessile bacteria: an important component of the microbial population in small mountain streams. Limnol. Oceanogr. 23, 1214-1223.

Geesey, G.G., Jang, L., Jolley, J.G., Hankins, M.R., Iwaoka, T., Griffiths, P.R., 1988. Binding of metal ions by extracellular polymers of biofilm bacteria. Water Sci. Technol. 20, 161-165.

Ghiorse, W.C., 1984. Biology of iron- and manganese-depositing bacteria. Annu. Rev. Microbiol. 38, 515-550.

Habte, M., Barrion, M., 1984. Interaction of Rhizobium sp. with toxin producing fungus in culture medium and in a tropical soil. Appl. Environ. Microbiol. 47, 1080-1083.

Hart, B.T., 1982. Uptake of trace metals by sediments and suspended particulates: a review. Hydrobiologia 91, 299-313.

Heijnen, C.E., van Veen, J.A., 1991. A determination of protective microhabitats for bacteria introduced into soil. FEMS Microbiol. Ecol. 85, 73-80.

Heijnen, C.E., Hok-A-Hin, C.H., van Veen, J.A., 1991. Protection of Rhizobium by bentonite clay against predation by flagellates in liquid cultures. FEMS Microbiol. Ecol. 85, 65-72.

Heijnen, C.E., Hok-A-Hin, C.H., van Veen, J.A., 1992. Improvements to the use of bentonite clay as a protective agent, increasing survival levels of bacteria introduced into soil. Soil Biol. Biochem. 24, 533-538.

Heynen, C.E., van Elsas, J.D., Kuikman, P.J., van Veen, J.A., 1988. Dynamics of Rhizobium leguminosarum biovar trifolii introduced in soil; the effect of bentonite clay on predation by protozoa. Soil Biol. Biochem. 20, 483-488.
Hughes, M.N., Poole, R.K., 1989. Metal mimicry and metal limitation in studies of metal-microbe interactions. In: Poole, R.K., Gadd, G.M. (Eds.), Metal-Microbe Interactions, IRL Press, Oxford, pp. 1-17.

Inoue, K., Huang, P.M., 1985. Influence of citric acid on the formation of short-range ordered aluminosilicates. Clays Clay Miner. 33, 312-322.

Inoue, K., Huang, P.M., 1986. Influence of selected organic ligands on the formation of allophane and imogolite. Soil Sci. Soc. Am. J. 50, 1623-1633.

Konhauser, K.O., 1997. Bacterial iron biomineralisation in nature. FEMS Microbiol. Rev. 20, 315-326.

Konhauser, K.O., 1998. Diversity of bacterial iron mineralisation. Earth Sci. Rev. 43, 91-121.

Konhauser, K.O., Ferris, F.G., 1996. Diversity of iron and silica precipitation by microbial mats in hydrothermal waters, Iceland: implications for Precambrian iron formations. Geology 24, 323-326.

Konhauser, K.O., Fyfe, W.S., Ferris, F.G., Beveridge, T.J., 1993. Metal sorption and mineral precipitation by bacteria in two Amazonian river systems: Rio Solimões and Rio Negro, Brazil. Geology 21, 1103-1106.

Konhauser, K.O., Schultze-Lam, S., Ferris, F.G., Fyfe, W.S., Longstaffe, F.J., Beveridge, T.J., 1994a. Mineral precipitation by epilithic biofilms in the Speed River, Ontario, Canada. Appl. Environ. Microbiol. 60, 549-553.

Konhauser, K.O., Fyfe, W.S., Kronberg, B.I., 1994b. Multi-element chemistry of some Amazonian waters and soils. Chem. Geol. 111, 155-175.

Konhauser, K.O., Powell, M.A., Fyfe, W.S., Longstaffe, F.J., Tripathy, S., 1997. Trace element chemistry of major rivers in Orissa State, India. Environ. Geol. 29, 132-141.

Konhauser, K.O., Fisher, Q.J., Fyfe, W.S., Longstaffe, F.J., Powell, M.A., 1998. Authigenic mineralization and detrital clay binding by freshwater biofilms: the Brahmani River, India. Geomicrobiol. J. 15, 209-222.

Kostka, J.E., Stucki, J.W., Nealson, K.H., Wu, J., 1996. Reduction of structural $\mathrm{Fe}$ (III) in smectite by a pure culture of Shewanella putrefaciens strain MR-1. Clays Clay Miner. 44, 522-529.

Lewandowski, Z., Stoodley, P., Altobelli, S., 1995. Experimental and conceptual studies on mass transport in biofilms. Water Sci. Technol. 31, 153-162.

Little, B.J., Wagner, P.A., Lewandowski, Z., 1997. Spatial relationships between bacteria and mineral surfaces. In: Banfield, J.F., Nealson, K.H. (Eds.), Geomicrobiology: Interactions Between Microbes and Minerals. Min. Soc. Am., Vol. 35. Washington, DC, pp. 123-159.

Lovley, D.R., Phillips, E.J.P., 1986. Organic matter mineralization with reduction of ferric iron in anaerobic sediments. Appl. Environ. Microbiol. 51, 683-689.

Lovley, D.R., Phillips, E.J.P., 1987. Rapid assay for microbially reducible ferric iron in aquatic sediments. Appl. Environ. Microbiol. 53, 1536-1540.

Mann, S., 1988. Molecular recognition in biomineralization. Nature 332, 119-124.

Marquis, R.E., Mayzel, K., Carstensen, E.L., 1976. Cation ex- 
change in cell walls of Gram-positive bacteria. Can. J. Microbiol. 22, 975-982.

Marshall, K.C., 1968. Interaction between colloidal montmorillonite and cells of Rhizobium species with different ionogenic surfaces. Biochim. Biophys. Acta 156, 179-186.

Marshall, K.C., 1969. Studies by microelectrophotetic and microscopic techniques of the sorption of illite and montmorillonite to Rhizobia. J. Gen. Microbiol. 56, 301-306.

Martinelli, L.A., Victoria, R.L., Dematte, J.L.I., Richey, J.E., Devol, A.H., 1993. Chemical and mineralogical composition of Amazon River floodplain sediments, Brazil. Appl. Geochem. 8, 391-402.

Mills, A.L., Maubrey, R., 1981. Effect of mineral composition on bacterial attachment to submerged rock surfaces. Microb. Ecol. 7, 315-322.

Mullen, M.D., Wolf, D.C., Ferris, F.G., Beveridge, T.J., Flemming, C.A., Bailey, G.W., 1989. Bacterial sorption of heavy metals. Appl. Environ. Microbiol. 55, 3143-3149.

Parfitt, R.L., 1990. Allophane in New Zealand - a review. Aust. J. Soil Res. 28, 343-360.

Parks, G.A., 1965. The isoelectric points of solid oxides, solid hydroxides, and aqueous hydroxo complex systems. Chem. Rev. 65, 177-198.

Roden, E.E., Zachara, J.M., 1996. Microbial reduction of crystalline Fe(III) oxides: influence of oxide surface area and potential for cell growth. Environ. Sci. Technol. 30, 16181628.

Sánchez-Navas, A., Martín-Algarra, A., Nieto, F., 1998. Bacterially mediated authigenesis of clays in phosphate stromatolites. Sedimentology 45, 519-533.

Schwertmann, U., Fechter, H., 1982. The point of zero charge of natural and synthetic ferrihydrites and its relation to adsorbed silicate. Clay Minerals 17, 471-476.

Steefel, C.I., van Cappellen, P., 1990. A new kinetic approval to modeling water-rock interaction: the role of nucleation, precursors, and Ostwald ripening. Geochim. Cosmochim. Acta 54, 2657-2677.

Stone, A.T., 1997. Reactions of extracellular organic ligands with dissolved metal ions and mineral surfaces. In: Banfield, J.F., Nealson, K.H. (Eds.), Geomicrobiology: Interactions Between Microbes and Minerals. Min. Soc. Am., Vol. 35. Washington, DC, pp. 309-344.

Stotzky, G., 1985. Mechanisms of adhesion to clays, with reference to soil systems. In: Savage, D.C., Fletcher, M. (Eds.), Bacterial Adhesion: Mechanisms and Physiological Significance. Plenum, New York, pp. 195-251.

Stotzky, G., Rem, L.T., 1966. Influence of clay minerals on microorganisms: 1. Montmorillonite and kaolinite on bacteria. Can. J. Microbiol. 12, 547-563.

Stumm, W., Morgan, J.J., 1996. Aquatic Chemistry. Wiley, New York, 1022 pp.
Sverjensky, D.A., Sahai, N., 1996. Theoretical prediction of single-site surface-protonation equilibrium constants for oxides and silicates in water. Geochim. Cosmochim. Acta 60, 37733797.

Tazaki, K., 1997. Biomineralization of layer silicates and hydrated $\mathrm{Fe} / \mathrm{Mn}$ oxides in microbial mats: an electron microscopical study. Clays Clay Miner. 45, 203-212.

Tazaki, K., Fyfe, W.S., Iizumi, S., Sampei, Y., Watanabe, H., Goto, M., Miyake, Y., Noda, S., 1994. Clay aerosols and arctic ice algae. Clays Clay Miner. 42, 402-408.

Thompson, J.B., Ferris, F.G., 1990. Cyanobacterial precipitation of gypsum, calcite, and magnesite from natural alkaline lake water. Geology 18, 995-998.

Thompson, J.B., Schultze-Lam, S., Beveridge, T.J., Des Marais, D.J., 1997. Whiting events: biogenic origin due to the photosynthetic activity of cyanobacterial picoplankton. Limnol. Oceanogr. 42, 133-141.

Tipping, E., 1981. The adsorption of aquatic humic substances by iron oxides. Geochim. Cosmochim. Acta 45, 191-199.

Urrutia, M.M., Beveridge, T.J., 1993. Mechanism of silicate binding to the bacterial cell wall in Bacillus subtilis. J. Bacteriol. 175, 1936-1945.

Urrutia, M.M., Beveridge, T.J., 1994. Formation of fine-grained metal and silicate precipitates on a bacterial surface (Bacillus subtilis). Chem. Geol. 116, 261-280.

Urrutia, M.M., Beveridge, T.J., 1995. Formation of short-range ordered aluminosilicates in the presence of a bacterial surface (Bacillus subtilis) and organic ligands. Geoderma 65, 149165.

Urrutia, M.M., Kemper, M., Doyle, R., Beveridge, T.J., 1992. The membrane-induced proton motive force influences the metal binding ability of Bacillus subtilis cell walls. Appl. Environ. Microbiol. 58, 3837-3844.

van Cappellen, P., Gaillard, J.F., 1996. Biogeochemical dynamics in aquatic sediments. In: Lichtner, P.C., Steefel, C.I., Oelkers, E.H. (Eds.), Reactive Transport in Porous Media. Min. Soc. Am., Vol. 34. Washington, DC, pp. 335-376.

Wada, K., 1989. Allophane and imogolite. In: Dixon, J.B., Weed, S.B. (Eds.), Minerals in Soil Environments. Soil Sci. Soc. Am., Madison, pp. 1051-1088.

Walker, S.G., Flemming, C.A., Ferris, F.G., Beveridge, T.J., Bailey, G.W., 1989. Physiochemical interaction of Escherichia coli cell envelopes and Bacillus subtilis cell walls with two clays and ability of the composite to immobilize heavy metals from solution. Appl. Environ. Microbiol. 55, 2976-2984.

Warren, L.A., Ferris, F.G., 1998. Continuum between sorption and precipitation of $\mathrm{Fe}$ (III) on microbial surfaces. Environ. Sci. Technol. 32, 2331-2337.

Williams, L.A., Crerar, D.A., 1985. Silica diagenesis: 11. General mechanisms. J. Sediment. Petrol. 55, 312-321. 